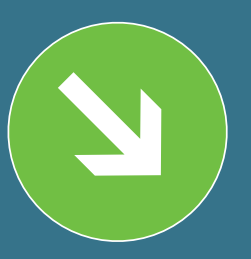

Ключевые слова: станкостроение, металлообрабатывающее оборудование, импортозамещение, литье

\section{АТОМНОЕ СТАНКОСТРОЕНИЕ}

\author{
Рассмотрен потенциал предприятий, входящих в Госкорпорацию \\ «Росатом», по выпуску металлообрабатывающего оборудования для \\ решения задач импортозамещения в станкостроении. Анонсирована \\ стратегия развития предприятий ГК «Росатом» в части создания но- \\ вых образцов современного металлообрабатывающего оборудования, \\ российского центра литья и чистовой обработки станин, производ- \\ ства инструмента и системы чПУ.
}

\section{ВВЕДЕНИЕ}

Основная деятельность предприятий оборонно-промышленного комплекса Российской Федерации (ОПК) направлена на поддержание ядерного потенциала РФ на высоком научно-техническом и технологическом уровне. Проводимые на регулярной основе мероприятия по повышению конкурентоспособности, технологической модернизации и совершенствованию системы управления ядерно-оружейным комплексом (ЯОК) направлены на выполнение этой важнейшей задачи.

В настоящее время одним из приоритетов в деятельности ЯОК является использование производственных мощностей, научных и технологических разработок, интеллектуального потенциала входящих в его структуру организаций для создания и развития высокотехнологичной продукции гражданского назначения.

За более чем 70 лет существования атомной отрасли создан огромный задел, который может использоваться при производстве оборудования для стратегических отраслей промышленности, таких как ОПК, топливно-энергетический комплекс, электроэнергетика, металлургия, судои авиастроение и др. В их числе находится и отрасль станкостроения, перед которой стоят задачи импортозамещения и обеспечения импортонезависимости.

\section{ПРОИЗВОДСТВО МЕТАЛЛООБРАБАТЫВАЮЩЕГО ОБОРУДОВАНИЯ}

Для решения задач импортозамещения в станкостроении, устойчивого обеспечения потребностей внутренних и внешних заказчиков в россий-

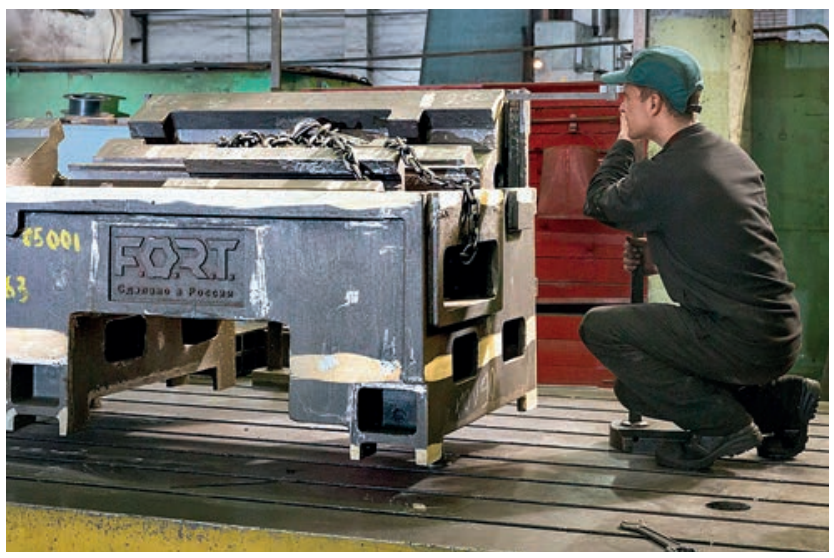

ском металлообрабатывающем оборудовании на двух предприятиях ЯОК - ФГУП «Приборостроительный завод» (ФГУП «ПСЗ») и АО «ФНПЦ «ПО «Старт» им. М.В. Проценко» - организовано производство современных обрабатывающих станков и инструмента уровня мировых производителей. Для производства современного металлообрабатывающего оборудования организации Росатома располагают всеми необходимыми технологиями и мощностями.

На ФГУП «ПСЗ» организована промышленная сборка и производство отдельных узлов и запчастей станочного оборудования с ЧПУ под торговой маркой «F.O.R.T.». Производственная серия представлена горизонтально-расточными станками с широким модельным рядом: от простых универсальных станков до тяжелых станков с подвижной колонной и ползуном. В зависимости от требований по обработке, оборудование имеет различную конструкцию: от классической, с крестообразным столом, до станков с подвижной колонной. 
Фрезерные обрабатывающие центры представлены различными компоновками: от классических станков с вертикальным и горизонтальным шпинделем до станков с поворотной угловой головой и станков портального типа. Для расширения технологических возможностей данное металлообрабатывающее оборудование может оснащаться дополнительными поворотными столами с 4-й или 4-й/5-й осями.

Помимо этого, ФГУП «ПСЗ» производит станки гидроабразивной и плазменной резки, а также электроэрозионные и шлифовальные станки. Все станки гидроабразивной и плазменной резки разработаны специально для работы в тяжелых условиях. Для обеспечения еще большей точности станки гидроабразивной резки могут оснащаться различным набором опциональных принадлежностей. Электроэрозионные станки представлены классическими проволочно-вырезными и прошивными станками, а также станками для прожига отверстий малого диаметра. Для прецизионной обработки деталей рекомендовано использование латунной проволоки.

Широкая группа шлифовального оборудования позволяет выполнять все виды шлифовок деталей различных габаритных размеров. Для выполнения шлифования крупногабаритных деталей типа «тел вращения» имеются модели карусельно-шлифовального оборудования.

Проект реализуется совместно с ЗАО «Балтийская Промышленная Компания». В перспективе $100 \%$-ное изготовление современных станков из отечественных компонентов на территории Российской Федерации.

АО «ФНПЦ «ПО «Старт» в рамках соглашения с ООО «Средневолжский станкозавод» освоил выпуск линейки высокопрецизионных станков (класс точности А), соответствующих современным тенденциям обработки металлов резанием, промышленного дизайна, эргономики и повышенным требованиям безопасности. Широкая номенклатура токарных станков позволяет выполнять обработку как мелких, так и крупногабаритных деталей. В целях автоматизации производства станки могут оснащаться устройствами для подачи прутка и автоматической загрузки прутка, роботами-манипуляторами, противошпинделем и фрезерной функцией.

В рамках мероприятий по импортозамещению металлообрабатывающего инструмента АО «ФНПЦ «ПО «Старт» при поддержке Росатома, усиливая позиции в этом критическом сегменте, создало производство высококачественного осевого инструмента, а также крепежных изделий для обеспечения собственных потребностей и удовлетворения имеющегося спроса организаций атомной отрасли, а также компаний других отраслей.

В 2013 году подтверждено качество продукции - проведена сертификация в Федеральном агентстве по техническому регулированию и метрологии. Использование производственными предприятиями России режущего инструмента отечественного производителя будет способствовать снижению рисков зависимости от импортных поставок, сокращению сроков поставки, уменьшению затрат на режущий инструмент по сравнению с аналогичной продукцией зарубежного производства.

\section{ЛИТЬЕ КОМПЛЕКТУЮЩИХ ИЗДЕЛИЙ ДЛЯ СТАНКОСТРОЕНИЯ}

Литейный завод «Петрозаводскмаш» Росатома, который является одним из ведущих предприятий России по изготовлению чугунных отливок самой сложной конфигурации массой до 120 т, начал осваивать литье комплектующих для станков в начале 2000-х годов. Упор был сделан на высокотехнологичные крупногабаритные изделия. Уникальные возможности литейного производства привлекли к ООО «Литейный завод «Петрозаводскмаш» производителей металлообрабатывающего оборудования. В 2007 году для краснодарского СП «Седин-ШИСС» завод поставил первые планшайбы и основания станков. Габариты деталей - до 3,5 м в диаметре, масса до 22 т. В процессе освоения новой продукции пришлось многому научиться - этого потребовала технология изготовления форм для станкостроительного литья, которая по сложности на порядок выше, чем характерное для завода машиностроительное литье. Чтобы получить требуемую геометрию будущей отливки, нужно собрать форму со стержнями, которые формируют внутренние полости изделия. При изготовлении форм для планшайб формовщики освоили новую технологию сборки: стержни не устанавливали в нижнюю полуформу, а подвешивали к верхней. В дальнейшем контракты на поставку станочного литья заключили в 2008 году с чешской фирмой Cilso International, входящей в состав холдинга TshKD-Blansco. Диаметры планшайб для карусельного станка этой фирмы составили уже 4 и 6,3 м. Кроме планшайб, изготовили различные детали для крупных металлообрабатывающих станков: стойки, основания, станины. Самая крупная станина весила, как самолет «Боинг 737-100», - 49 т. Ее длина составила 8,7 м, ширина и высота - 2,6 и 1,4 м соответственно.

26 июля 2017 года в Петрозаводске АО «Атомэнергомаш» (машиностроительный дивизион 
Госкорпорации «Росатом») заключило Соглашение о намерениях с концерном DMG MORI AG, немецким подразделением одного из ведущих мировых производителей станков - компании DMG MORI.

B Соглашении стороны заявили о заинтересованности в долгосрочном сотрудничестве и реализации совместных проектов по локализации производства станкоинструментальной продукции. Согласно подписанному документу, предприятие АО «Атомэнергомаш» - ООО «Литейный завод «Петрозаводскмаш» - будет поставлять чугунные отливки компонентов станков для Ульяновского станкостроительного завода и европейских заводов DMG MORI.

Литейный завод «Петрозаводскмаш» уже поставил партию отливок станин токарного станка CTX-310 для Ульяновского станкостроительного завода. Станины были приняты к серийному производству, и стороны приняли решение расширить сотрудничество. Литейный завод выражает готовность обеспечить производство литых компонентов станков в объеме не менее $80 \%$ потребности ульяновских станкостроителей. В свою очередь, компания DMG MORI выражает заинтересованность в размещения заказов на литые комплектующие в интервале 2025-2030 годов, в том числе для европейских заводов концерна.

Помимо Ульяновского станкостроительного завода, партнерами предприятия являются такие компании как «Группа СТАН», Станкозавод «САСТА», «Балтийская Промышленная Компания», «Минский станкостроительный завод», «Приборостроительный завод», «Ковровский электромеханический завод», «Краснодарский завод тяжелого станкостроения».

\section{СТРАТЕГИЯ РАЗВИТИЯ}

Предприятия Росатома рассматривают и в дальнейшем возможности создания новых образцов современного металлообрабатывающего оборудования, российского центра литья и чистовой обработки станин, производства отечественного инструмента, разработки и производства отечественной системы ЧПУ и другие проекты.

В сентябре 2016 года ФГУП «ПСЗ» защитил отраслевую продуктовую стратегию по направлению «Станкостроение», в которой установлены целевые бизнес-показатели предприятий-участников до 2030 года. Как ожидается, в 2020 году консолидированная выручка по предприятиям, которые войдут в масштабный проект Росатома кроме ФГУП «ПСЗ» и «Петрозаводскмаш», это и НИИИС, ПО «Север», ПО «Старт», АЭМ-Технологии и др., - составит 8,3 млрд руб. В рамках
ПЛАНЫ РОСАТОМА

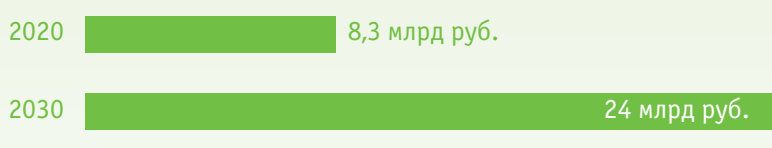

прогноз по выпуску продукции
500 станков

план на 2024 год
$15-20 \%$

российского рынка планирует охватить ФГУП «ПСЗ» с партнерами
Puc. 1. Планы Росатома по выпуску станочной продукции

Источник: www.atomicexpert.com

отраслевой стратегии предполагается организовать производство отечественных станков с уровнем локализации до $70 \%$ в 2030 году. В обозримом будущем планируется создание отдельной бизнес-единицы, которой ФГУП «ПСЗ» передаст функции интегратора в станкостроении. За продажи и сервис при этом предприятия будут отвечать самостоятельно, каждое по своей группе продукции. В частности, ФГУП «ПСЗ» будет нести ответственность за продажи и сервис оборудования «F.O.R.T». Планы Росатома по выпуску станочной продукции представлены на рис. 1.

\section{ПОТРЕБНОСТИ РОСАТОМА}

В рамках подготовки стратегии развития бизнеса «Станкостроение» в Росатоме было проведено несколько маркетинговых исследований, направленных на изучение потребности организаций атомной отрасли в металлообрабатывающем оборудовании. Практически по каждому предприятию был получен прогноз на средне- и долгосрочную перспективу. Для большинства проектов технического перевооружения и модернизации отраслевых организаций уже утверждены соответствующие федеральные целевые программы. По оценкам Росатома, годовая потребность организаций отрасли составляет от 5 до 10 млрд руб. в год в зависимости от планов закупок.

\footnotetext{
Материал подготовил С.В. НОВикоВ

При подготовке статьи использованы материалы сайтов wWw.rosatom.ru, www.atomicexpert.com u www.vestnik-aem.ru.
} 
19-я Международная выставка сварочных материалов, оборудования

\section{weldéx россварка}

и технологий

15-18 октября 2019

Москва, КВЦ «Сокольники»

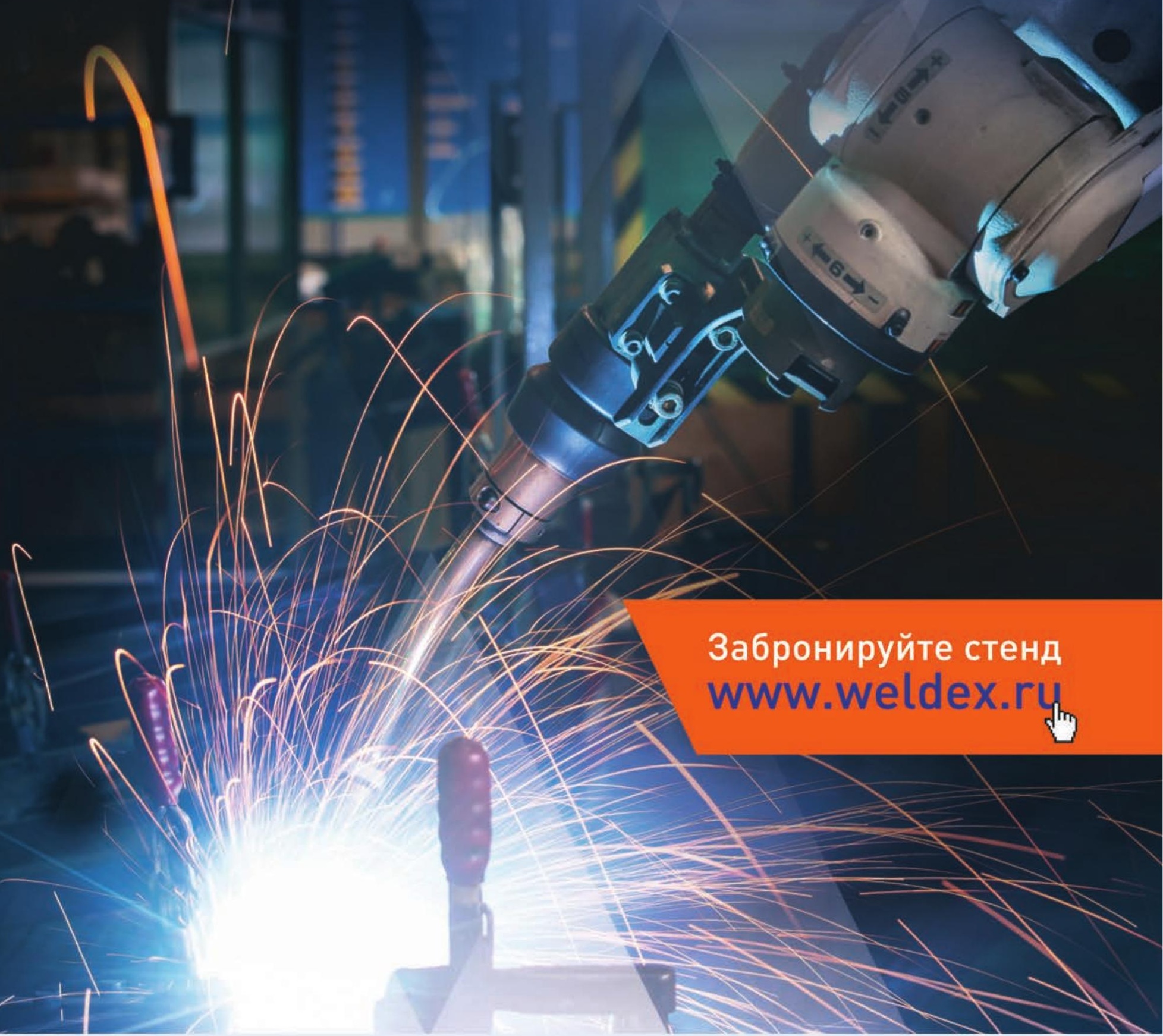

Официальная поддержка: А РОССпРомторг Mmarc: Pkcaiop

Генеральный информационный партнер: 